\title{
Advanced Spheroid, Tumouroid and 3D Bioprinted In-Vitro Models of Adult and Paediatric Glioblastoma
}

\author{
Louise Orcheston-Findlay $^{1} \mathbb{D}$, Samuel Bax ${ }^{1}$, Robert Utama ${ }^{2}$, Martin Engel ${ }^{2} \mathbb{D}$, Dinisha Govender ${ }^{3}$ \\ and Geraldine $O^{\prime}$ Neill $1,4,5, *$ (D)
}

1 Children's Cancer Research Unit, The Children's Hospital at Westmead, Sydney, NSW 2145, Australia; Louise.OrchestonFindlay@health.nsw.gov.au (L.O.-F.); Samuel.Bax@health.nsw.gov.au (S.B.)

2 Inventia Life Science Pty Ltd., Sydney, NSW 2015, Australia; Robert.Utama@inventia.life (R.U.); Martin.Engel@inventia.life (M.E.)

3 Cancer Centre for Children, The Children's Hospital at Westmead, Sydney, NSW 2145, Australia; Dinisha.Govender@health.nsw.gov.au

4 Children's Hospital at Westmead Clinical School, Faculty of Medicine and Health, University of Sydney, Sydney, NSW 2145, Australia

5 School of Medical Sciences, Faculty of Medicine and Health, University of Sydney, Sydney, NSW 2145, Australia

* Correspondence: Geraldine.ONeill@health.nsw.gov.au

Citation: Orcheston-Findlay, L.; Bax, S.; Utama, R.; Engel, M.; O'Neill, G. Advanced Spheroid, Tumouroid and 3D Bioprinted In-Vitro Models of Adult and Paediatric Glioblastoma. Int. J. Mol. Sci. 2021, 22, 2962. https://doi.org/10.3390/ ijms 22062962

Academic Editor: Michele Caraglia

Received: 26 February 2021

Accepted: 5 March 2021

Published: 15 March 2021

Publisher's Note: MDPI stays neutral with regard to jurisdictional claims in published maps and institutional affiliations.

Copyright: (c) 2021 by the authors. Licensee MDPI, Basel, Switzerland. This article is an open access article distributed under the terms and conditions of the Creative Commons Attribution (CC BY) license (https:// creativecommons.org/licenses/by/ $4.0 /)$.

\begin{abstract}
The life expectancy of patients with high-grade glioma (HGG) has not improved in decades. One of the crucial tools to enable future improvement is advanced models that faithfully recapitulate the tumour microenvironment; they can be used for high-throughput screening that in future may enable accurate personalised drug screens. Currently, advanced models are crucial for identifying and understanding potential new targets, assessing new chemotherapeutic compounds or other treatment modalities. Recently, various methodologies have come into use that have allowed the validation of complex models-namely, spheroids, tumouroids, hydrogel-embedded cultures (matrix-supported) and advanced bioengineered cultures assembled with bioprinting and microfluidics. This review is designed to present the state of advanced models of HGG, whilst focusing as much as is possible on the paediatric form of the disease. The reality remains, however, that paediatric HGG (pHGG) models are years behind those of adult HGG. Our goal is to bring this to light in the hope that pGBM models can be improved upon.
\end{abstract}

Keywords: glioma; model; microenvironment; spheroid; tumouroid; organoid; bioprinting; microfluidics

\section{Introduction}

Patients with high-grade glioma (HGG) brain tumours, including adult glioblastoma (GBM) and paediatric gliomas including paediatric GBM (PGBM) and diffuse midline glioma (DMG) have a five-year survival rate of 20\% [1] and 5\% [2], respectively. The treatment regime for adults is surgery, radiotherapy and chemotherapy, to which less than half of patients respond and the remainder gain only a few additional months of life [1,3]. There is no standard chemotherapy regimen designed for paediatric HGG (PHGG) and patients are given radiotherapy and/or surgery on a case-by-case basis [4-8] - there is no evidence that Temozolomide is beneficial $[7,9,10]$.

The fate of HGG patients has improved only marginally in the last 40 years $[6,10]$ and given intrinsic drug resistance and difficulty or impossibility of removal [5,11-13], there is an urgent need for effective therapies.

High-grade glioma cells exhibit both individual and collective modes of migration, influenced by cell-cell connections between neighbouring glioma cells and neural cells, and by the physico-chemical features of the surrounding brain tissue [14-18]. Previous models of diffuse intrinsic pontine glioma (DIPG) (recently reclassified as a subgroup of 
DMG) have suggested that cells disseminate throughout the pons both individually and collectively [19], although this study investigated adult GBM lines injected into the pons and the implications for DMG specifically therefore remain to be confirmed. More recently, cooperativity between different DMG subclones resulted in enhanced invasive capacity of otherwise poorly invasive DMG subclones [20]. Furthermore, the inter- and intratumoural heterogeneity is extreme [21,22], resulting in inaccurate or misleading predictions of clinical response from simplified laboratory models-wasting precious time and resources.

In this review, an introduction to crucial aspects for modelling HGGs in adults and children will be given. This will be followed by a comparison of several methods for the generation of sophisticated preclinical models that incorporate the required attributes in a controlled manner. Notably, modelling of adult HGG has progressed further than PHGG, thus where possible we extrapolate from models of HGG and consider how they might be applied in studies of PHGG.

\section{The Tumour Microenvironment}

The location of GBM is a significant barrier to successful treatment. As well as making surgical resection difficult, the extracellular matrix (ECM) composition [23,24], tissue mechanics $[15,25]$ and stromal-cell interactions [26-28] within the brain elicit unique tumour qualities. The brain provides tissue niches for stem-like cancer stem cells (CSCs) and hypoxic regions develop, which further enables drug resistance and recurrence $[29,30]$. Each of these will be briefly introduced before progressing to discussions of their controlled incorporation into disease models.

\subsection{Glioma Stem Cells}

The population of radially migrating cells at the periphery of HGGs commonly host CSCs-also termed glioma stem cells (GSCs) and glioma initiating cells (GICs) [31-35] that can self-renew [36], are drug resistant and radioresistant $[27,32,34,37]$ and indicate poor prognosis [11,38]. Studies suggest that CSCS are also present in DMG [35]. They are thought to be a key contributor to high recurrence rates and therapy resistance $[30,36,39]$.

\subsection{Hypoxia}

Dense and fast-growing regions of GBM host sharp solute gradients [40]. As a result, hypoxia forms, which increases drug resistance [41]. It appears that hypoxia is also a factor in both PHGG and DMG [42,43]. Furthermore, via the increased expression of hypoxia inducible factors (HIFS), the stem-like functions of CSCS are thought to be enhanced [44]. The hypoxic landscape is heterogeneous between tumours and patients [40], so modelling this in a patient-specific manner is not trivial.

\subsection{Extracellular Matrix}

The ECM composition of healthy brain is almost void of fibrous proteins seen in high concentrations in other parts of the body [44,45]. It is instead rich in glycosaminoglycans (GAGs), among these, hyaluronic acid (HA) —a GAG that regulates brain tissue mechanics, organisation and signalling $[44,46]$-is present in brain ECM in high concentrations $[15,38]$. In GBMs, GAGs are overexpressed compared to normal brain three- to four-fold and are associated with increased proliferation, invasion, resistance, recurrence and poor prognosis [47]. Fibrillar collagens are upregulated in subsets of gliomas, thus potentially influence glioma behaviour within the tumour mass [15]. Cells can disseminate along the basement membrane lining blood vessels in the brain, rich in laminins and collagen IV [14]. Thus, it is essential to incorporate or mimic these ECM components as part of pre-clinical models.

\subsection{Tumour Interactions with Non-Tumour Cells}

The tumour stroma may provide a supportive niche for CSCS, driving invasion and recurrence [26], however the inflammatory microenvironment of PHGG is reported to be fundamentally different to that of adult HGG. Reports suggest the presence of 
a stem cell population present in adjacent healthy stroma, termed glioma associated mesenchymal stem cells (GA-MSCs), has been shown to excrete exosomes that increase the proliferation of CSCS. Furthermore, CSCs pre-treated with exosomes derived from GAMSCs decreased the survival of the mice in which they were implanted [26]. Glioblastoma cells are also known to induce co-expression with surrounding GA-MSCs [12] and recruit and polarise tumour-associated macrophages to aid in their continued proliferation and survival [48].

Interactions between tumour cells and healthy neuronal cells also play a role [49]. Increased neural activity in PGBM patient-derived xenograft (PDX) models resulted in increased tumour proliferation [49]. Moreover, GBMs contain sub-populations that resemble oligodendroglial precursor cells (OPCs) that express numerous synaptic genes and have been observed to form synapses with healthy neurons [49]. This activity is thought to support progression $[28,49]$ and highlights the need to consider the contribution of healthy brain tissue in models of HGG.

\subsection{Tumour Microtubules}

In recent years, tumour microtubules (TMs) have been suggested to have an important role in GBM invasion and survival [29]. Their presence is highly influenced by tumour type and grade and is significantly correlated with poor prognosis [16,30]. Additionally, it appears that DMG may similarly elaborate tumour microtube connections [49]. Tumour microtubules interconnect the cytoplasm of cells through gap junctions and are responsible for two distinct functionalities $[16,29,30]$; (i) to probe the environment at the leading edge of the tumour and subsequently direct invasion and (ii) to provide connections between a proportion of single glioma cells [16,29]. Together, this results in a large network of functional and resistant glioma cells that is able to repair damaged cells within and around the network $[16,29]$. Several mechanisms of therapy resistance linked to these systems have been suggested $[16,29]$. For example, through the distribution-and subsequent dilution-of toxicity and the replacement of damaged cell components.

\subsection{Mechanical Properties}

The brain is viscoelastic and is reported to have a particularly low physical stiffness of around 1-10 $\mathrm{kPa}$ [50] that varies depending on the brain region and over micron-scale distances [46,51]. Glioblastomas are most frequently seen to arise in the frontal and temporal lobes of the cerebral hemispheres, while DMG comprises tumours in the midbrain and within as well as outside the brainstem. The brainstem has been reported to be the stiffest of the brain regions [52] and thus in future it will be important to consider this parameter in models of brain cancer, matching the tumours to the biomechanical features of their anatomical location. It has now been established that through the secretion and organisation of a dense fibrillar matrix, many solid tumours become increasingly stiff, resulting in tumour progression [53]. Thus, it is important to establish whether HGG similarly display a rigid matrix relative to the surrounding soft tissue. Current reports of the mechanical properties of GBMs suggest that the tumours are alternatively either stiffer or softer than surrounding healthy brain $[44,46,54]$. These opposite results may stem from differing measurement techniques. Most measurements are performed on ex-vivo brains, contrasting more recent applications of magnetic resonance elastography (MRE) (see Box 1) where imaging is performed on intact brains in-vivo. A significant limitation of all analyses of the mechanical properties of tissues is that the readout depends on the precise parameters (application and duration of force, for example) and technical approach used. Thus, to generate models that appropriately mimic the biomechanical features of the relevant brain tumour microenvironment (TME), approaches are required that allow direct comparison of the mechanical attributes of the model with tissue measurements. Recent successful adaptations of MRE analyses to small organoid cultures provide a potential avenue for this [55]. 


\section{Box 1. Magnetic Resonance Elastography.}

Recently, an established technique has been re-purposed to non-invasively characterise the viscoelastic properties of healthy brain [56] and its malignancies [57]. This technique, termed MRE, involves applying shear waves to the tissue of interest and observing their attenuation through the sample with magnetic resonance imaging (MRI), from which mechanical properties are extracted. This technique is traditionally applied clinically to stage liver fibrosis [58], but has more recently been validated for measuring mechanical properties of brain cancers [57]. The technique yields the storage modulus $\left(G^{\prime}\right)$, loss modulus $\left(G^{\prime \prime}\right)$ and phase angle $(\phi)$ for the tissue of interest measures of shear stiffness, shear viscosity and liquid/solid characteristics, respectively. The stiffness represents the deformation with applied shear force, the viscosity signifies the deformation over time while under a constant force and the phase angle denotes behaviour in the range from elastic solid to viscous liquid [54]. These are related via $\operatorname{Tan}(\phi)=G^{\prime} / G^{\prime \prime}$ and the complex modulus $\left|G^{*}\right|$, representing resistance to deformation, is equated to the stiffness and viscosity via $\left|G^{*}\right|=\sqrt{G^{\prime \prime 2}+G^{\prime 2}}[57]$.

Multifrequency MRE (MMRE) has been used to effectively probe the full range of viscoelastic behaviour in anisotropic brain tissues $[55,59]$. In GBMs, a wide range of $\left|G^{*}\right|$ values has been observed within and between tumours; broadly, there is an increased loss of stiffness the higher the grade and GBM is the softest of all primary brain tumours [60-62]. The complex modulus can be used to distinguish between GBM and normal-appearing white matter (NAWM) with a high degree of certainty [63], but such a large difference in $\left|G^{*}\right|$ is not always the case, as the data presented in Table 1 demonstrate. The phase angle, as well as a possible diagnostic factor, may also provide insight into the invasion of GBM into stiffer NAWM. Viscous fingering-a physical phenomenon where softer material is able to passively infiltrate stiffer material-has been suggested, rather than active tissue displacement by more rigid tumours [54]. Furthermore, the intertumoural heterogeneity of GBM has been demonstrated by a stiffness variance of more than $20 \%$ [64] and five out of 22 participants exhibited a GBM tumour that is stiffer than surrounding NAWM as measured by MRE [65]. It remains to be seen if this is a patient-specific trait.

Table 1. The complex modulus $\left|G^{*}\right|$ and phase angle $\phi$ in human GBM and NAWM measured using MRE, demonstrating its pre-operative diagnostic capabilities. Entries are presented in reverse date order.

\begin{tabular}{cccccccccc}
\hline \multirow{2}{*}{$\begin{array}{c}\text { Sample Size, } \\
\text { Age Range (y) }\end{array}$} & $\begin{array}{c}\text { Range of Excitation } \\
\text { Frequency (Hz) }\end{array}$ & \multicolumn{2}{c}{ Complex Modulus $\left|G^{*}\right|$ (rad) } & \multicolumn{4}{c}{ Phase Angle $\boldsymbol{\phi}$} \\
\cline { 3 - 7 } & & GBM & NAWM & $\frac{G B M}{N A W M}$ & GBM & NAWM & GBM & Ref. \\
\hline $9,60-80$ & $30-60$ & $1.10 \pm 0.29$ & $1.81 \pm 0.23$ & $0.65 \pm 0.04$ & $0.62 \pm 0.19$ & $0.36 \pm 0.10$ & $0.54 \pm 0.15$ & {$[54]$} \\
$6,25-68$ & 60 & $1.7 \pm 0.5$ & $3.3 \pm 0.7$ & - & - & - & - & {$[63]$} \\
$11,42-86$ & $30-60$ & $1.37 \pm 0.26$ & $1.64 \pm 0.21$ & $0.64 \pm 0.10$ & $0.85 \pm 0.22$ & $0.44 \pm 0.07$ & $0.70 \pm 0.11$ & {$[61]$} \\
$22,18-86$ & $30-60$ & $1.32 \pm 0.26$ & $1.54 \pm 0.27$ & $0.58 \pm 0.07$ & $0.88 \pm 0.19$ & $0.37 \pm 0.08$ & $0.66 \pm 0.15$ & {$[65]$} \\
$3,53-69$ & 45 & $1.24 \pm 0.31$ & $2.11 \pm 0.31$ & $0.41 \pm 0.06$ & $0.59 \pm 0.09$ & $0.30 \pm 0.04$ & $0.74 \pm 0.19$ & {$[60]$} \\
\hline
\end{tabular}

Accurate measurement of mechanical properties of HGGs and healthy brain tissue is crucial since it is a determinant of cell behaviour, including drug response [66], important for understanding HGG and other cancers as well as for guiding the production of representative models.

\section{Traditional In-Vitro Models of High Grade Glioma}

While much research has been undertaken using two-dimensional (2D) culture, it is increasingly appreciated that such models are ill equipped to reproduce the multifaceted characteristics of HGGs. Moreover, the use of continuously cultured cell lines that have been maintained in the presence of serum has been shown to significantly alter the cellular phenotype and genotype to the extent that they retain few features of the primary tumour [67]. 
Increasingly, studies employ patient-derived cell lines that are maintained in serum-free conditions, in neural-cell specific medium and at low passage to retain phenotypes and genotypes [68]. Thus, in this review we do not discuss analyses in standard 2D culture and focus on studies using patient-derived cell lines grown under serum-free conditions.

Mouse orthotopic xenografts of patient-derived cells display genetic heterogeneity [24] and patient-specific drug responses [69] and responses to fluid shear [70] and thus provide disease relevance. Pepin et al. found that IDH1-mutated PDX GBM models were significantly softer than wild-type GBM via MRE [63]. The reason for this-reducing tenascin C expression-was also discovered using mouse PDX models [71].

The caveats of mouse models are that tumours can take months to establish [72] and mice are commonly immunocompromised [73]. Humanised [25] and AVATAR mouse models [44] can address some of these issues, but ethical considerations prevent the use of animal models for high-throughput drug screening. There are published works that utilise mouse models for PGBM $[37,69]$ and DMG $[13,74]$ research, but for reasons stated above, the use of such mouse models is not the best solution for some applications. Alternative 3D modalities are becoming more sophisticated and may soon limit the need for animal models. These 3D models are the focus of the remainder of this article.

\subsection{Three-Dimensional In-Vitro Models of High Grade Glioma}

With the rapid development of new 3D culture methods, there is some confusion around the nomenclature used to describe different resulting cultures. The terms tumouroid and organoid are often used interchangeably, however this creates confusion when we then start to consider the combination of tumouroids (3D spheroid cultures derived directly from patient tumours) together with organoids (organ-like 3D cultures often derived from pluripotent stem cells) in order to provide an in-vivo-like tissue microenvironment for the tumour cells. Both tumouroids and organoids are 3D structures, composed of distinct cell types and grown under conditions to promote stem cell maintenance. However, while all tumouroids consist of malignant cells-with the exception of organoids, in which cancerpromoting mutations have been introduced $[75,76]$ —organoids comprise only 'normal' cells. For the purpose of this review, we provide specific definitions of glioma spheroids (GSs), glioma tumouroids (GTs) and brain organoids (BOs) (Table 2 and Figure 1). Each of these models can be cultured in liquid media, here referred to as 'free', or further developed by suspension in a 3D extra-cellular matrix, here referred to as 'matrix-supported', 'spheroid', 'tumouroid' or 'organoid', via the schema presented in Table 2 and depicted in Figure 1. This will aid in comparison between and within model types.

Table 2. Definitions of the different types of GBM/brain models used throughout this review to compare and contrast existing literature. All models can be matrix-supported or free.

\begin{tabular}{ll}
\hline Model Type & Definition \\
\hline Glioma spheroid (GS) (with serum) & Dense conglomerate of cells cultured in serum-growth of CSCs not specifically promoted. \\
\hline Glioma tumouroid (GT) & $\begin{array}{l}\text { Tumour organoids generated by growing primary tumour material in suspension under } \\
\text { defined media conditions in the absence of serum, CSCs specifically promoted and cellular } \\
\text { heterogeneity maintained. }\end{array}$ \\
\hline Brain organoid (BO) & $\begin{array}{l}\text { Derived from stem cells under specific media and growth conditions to promote tissue } \\
\text { lineage differentiation, displays some functionality and morphological features of model } \\
\text { organ. }\end{array}$ \\
\hline GS/BO and GT/BO & Glioma spheroid or tumouroid co-cultured with a BO. \\
\hline Free & Single cells/spheroid/tumouroid suspended in liquid medium. \\
\hline Matrix-supported & Single cells/spheroid/organoid encapsulated in a 3D matrix. \\
\hline
\end{tabular}


(a)

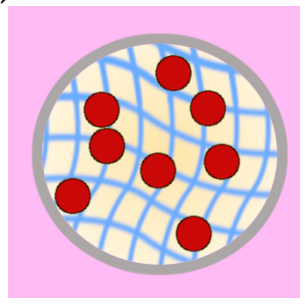

(b)

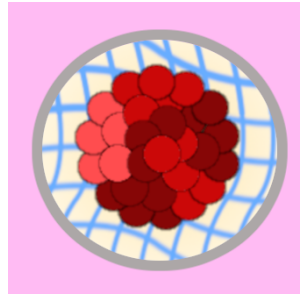

(c)

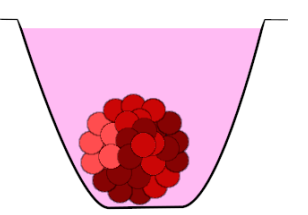

(d)

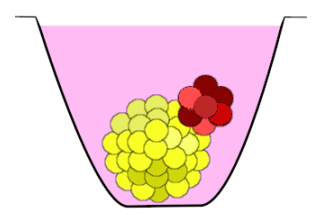

Figure 1. Schematics depicting various key culture modalities employed to model HGG. (a) matrix-supported cell suspension, (b) matrix-supported glioma spheroid (GS) or tumouroid (GT), (c) free spheroid and (d) free organoid/tumouroid (BO/GT) or organoid/spheroid (BO/GS) co-culture.

\subsection{Free Spheroid and Tumouroid Models}

Free 3D culture typically involves an aggregate of cells formed in a low-attachment dish/well [11,77] (as demonstrated in Figure 1), microfluidic chamber [78], or by suspension either by magnetic levitation [79], rotary cell culture system (RCCS) [73], or by hanging droplet.

GSs are formed from immortalised, or tumour-derived HGG cell lines under conditions which do not select for stem cell renewal. This contrasts with GTS, which are formed by culturing cells in media that promotes the maintenance of CSCS. GTs are also distinguished by the maintenance of increased cellular heterogeneity, which reflects the mixed cell populations that characterise tumours in-vivo [80].

Patient-specific therapy response [25] and retention of stemness $[12,33,76,81]$ in PGBM and gene expression profiles of adult GBM tumours are evidenced in free GTs [2]. GTs have been used to demonstrate the role of HDAC6 in temozolomide (TMZ) resistance [82], investigate hedgehog signaling [83] and identify aurora A kinase (AUKRA) as a potential drug target in PGBM [69,72]. Please see Table 3 for a list of methods for the formation of free tumouroids or spheroids.

Table 3. Key methods for the formation of free tumouroids and the findings generated with their use.

\begin{tabular}{|c|c|c|c|c|}
\hline Model Type & Cell Origin & Culture Method & Findings & Ref. \\
\hline \multicolumn{5}{|c|}{ Adult GBM } \\
\hline Free tumouroid & $\begin{array}{l}\text { Cerebral organoid } \\
\text { generated from HESC } \\
\text { cell line } \mathrm{H} 1 .\end{array}$ & $\begin{array}{l}\text { Oncogenesis transduced } \\
\text { with oncogene and } \\
\text { knockdown of p53. }\end{array}$ & $\begin{array}{l}\text { Tumouroids can be generated from } \\
\text { cerebral organoids via gene manipulation. }\end{array}$ & [75] \\
\hline Free tumouroid & $\begin{array}{l}\text { Dissociated GBM } \\
\text { specimens. }\end{array}$ & $\begin{array}{l}\text { Suspended in serum-free } \\
\text { media. }\end{array}$ & $\begin{array}{l}\text { Tumouroids recapitulated } \\
\text { the morphology and expression profile of } \\
\text { parent GBM tumours. }\end{array}$ & [3] \\
\hline $\begin{array}{l}\text { Free tumouroid } \\
\text { co-culture }\end{array}$ & $\begin{array}{l}\text { GA-MSCS and CSCS } \\
\text { were isolated from } \\
\text { surgical specimens of } \\
\text { GBM stroma and GBM, } \\
\text { respectively. }\end{array}$ & $\begin{array}{l}\text { Dissociated and } \\
\text { resuspended in liquid } \\
\text { differentiation media. }\end{array}$ & $\begin{array}{l}\text { Stromal GA-MSCS excrete exosomes that } \\
\text { increased proliferation of GSC xenografts } \\
\text { and decreased median survival of the host } \\
\text { animals when pre-treated with stromal } \\
\text { GA-MSCS-derived exosomes. }\end{array}$ & [26] \\
\hline $\begin{array}{l}\text { Free tumouroid/ } \\
\text { spheroid }\end{array}$ & $\begin{array}{l}\text { Patient-derived GSCS/ } \\
\text { cell line U87 }\end{array}$ & Non-adherent plates. & $\begin{array}{l}\text { All patient-derived tumouroids from } \\
\text { primary GSCS were Nestin and Sox } 2 \\
\text { positive. Chemotherapeutics were } \\
\text { effective only on 3D U87 spheroids. } \\
\text { Tumouroids from the one recurrent cell } \\
\text { line were the most drug-resistant. TMZ } \\
\text { efficacy was patient-specific. }\end{array}$ & [84] \\
\hline
\end{tabular}


Table 3. Cont.

\begin{tabular}{|c|c|c|c|c|}
\hline Model Type & Cell Origin & Culture Method & Findings & Ref. \\
\hline \multicolumn{5}{|c|}{ Paediatric GBM } \\
\hline $\begin{array}{l}\text { Ex-supported } \\
\text { tumouroid } \\
\text { (passaged in PDX } \\
\text { models then } \\
\text { extracted) }\end{array}$ & Specimens of PGBM & $\begin{array}{l}\text { Xenografts of human } \\
\text { PGBM patients with } \\
\text { therapy-naive, recurrent } \\
\text { and lethal disease were } \\
\text { extracted, minced and } \\
\text { enriched for CSCS. }\end{array}$ & $\begin{array}{l}\text { An AUKRA inhibitor was most effective } \\
\text { on therapy-naive tumouroids, followed } \\
\text { by recurrent ex-xenografted tumouroids. }\end{array}$ & [69] \\
\hline Free tumouroid & $\begin{array}{l}\text { Tumour specimens } \\
\text { from six PGBM } \\
\text { patients }\end{array}$ & $\begin{array}{l}\text { Stem cell population } \\
\text { expanded via specialised } \\
\text { media. }\end{array}$ & $\begin{array}{l}\text { EGFR and PDGFRA amplification and } \\
\text { deletion of RB1, CDKN2A/B \& PTEN was } \\
\text { observed. }\end{array}$ & [33] \\
\hline Free tumouroid & $\begin{array}{l}\text { Dissociated PGBM } \\
\text { specimens from two } \\
\text { patients }\end{array}$ & $\begin{array}{l}\text { Suspended in serum-free } \\
\text { media. }\end{array}$ & $\begin{array}{l}\text { Stemness markers nestin, CD133, Sox } 2 \text {, } \\
\text { melk, PSP and bmi- } 1 \text { were expressed. }\end{array}$ & [85] \\
\hline Free tumouroid & $\begin{array}{l}\text { Dissociated PGBM } \\
\text { specimens from } 14 \\
\text { patients }\end{array}$ & $\begin{array}{l}\text { Suspended in neural } \\
\text { stem-cell media. }\end{array}$ & $\begin{array}{l}\text { Stemness markers CD133 and Nestin were } \\
\text { expressed and self-renewal was retained } \\
\text { even when secondary tumouroids were } \\
\text { formed from a single cell. }\end{array}$ & [81] \\
\hline
\end{tabular}

\subsection{Matrix-Supported Spheroid and Tumouroid Models}

Matrix-supported 3D culture involves the use of either naturally occurring extracellular matrix extracts or synthetic scaffolds $[86,87]$. These act as porous support structures typically containing components of synthetic or animal-derived ECM [88]. Cell suspensions [1] or pre-formed GSS or GTs can be added to the gel precursors before crosslinking, which once polymerised, support the cells from all sides. Encapsulating matrices allow cells to produce their own native 3D ECM [44], which is advantageous for brain tissue culture $[38,45,47,66]$ and results in a gene expression profile closer to the parent tissue [2]. Pseudo-3D culture can also be performed by culturing cells on the surface of 3D hydrogels and immersed in liquid media [66].

Matrix-supported models have been developed using collagen I, laminin, gelatine, fibrin, HA and combinations thereof, the formulations of which have been extensively reviewed elsewhere $[44,88]$. Spheroids encapsulated in hydrogel droplets have been used to demonstrate the formation of central hypoxia [32] as well as providing a compact medium into which cells can migrate [1,15].

Since HA is present in high concentrations in brain ECM, and its stiffness can be tuned [38], HA-based hydrogels are particularly suited to supporting the culture of GBM. A higher concentration of HA was shown to induce resistance to erlotinib [47], TMZ [89] and dasatinib [89] in dissociated GTs [89] and single cells [47] within a HA-based gel and increased motility in cells cultured on the surface of gels [45]. Increased adhesion-mediated invasiveness was also observed [47].

Matrix-supported models are critical for analysing invasion, as they provide a replicate of the stroma surrounding tumours through which cancer cells must navigate in order to metastasise. Zhang et al. demonstrated this with spheroids and tumouroids formed from GBM cell line U251N and primary tumour specimens, and compared the migration through a collagen-based gel when treated with an experimental chemotherapy compound [1] Migration of cell sheets was also observed from the periphery of GSs encapsulated in reconstituted basement membrane (RBM)-based hydrogels containing HA, with a speed dependent on HA concentration. Furthermore, sheet-like migration was also observed in GTs implanted in rat brains, supporting the validity of the matrix-supported spheroid model [15]. 
Concerning PGBM, although there are over 60 PGBM cell lines in existence [90], there were no PGBM matrix-supported models available on PubMed at the time of writing. Table 4 contains details of studies utilising matrix-supported adult GBM models.

Table 4. Key methods for the formation of matrix-supported adult high-grade glioma spheroid and tumouroid models and the findings generated with their use. No matrix-supported models of paediatric HGG were found at the time of writing.

\begin{tabular}{|c|c|c|c|c|}
\hline Model Type & Cell Origin & Culture Method & Findings & Ref. \\
\hline $\begin{array}{l}\text { Matrix -supported } \\
\text { spheroid }\end{array}$ & $\begin{array}{l}\text { GBM lines E98, E468 \& } \\
\text { U-251MG }\end{array}$ & $\begin{array}{l}\text { Spheroids formed with } \\
\text { hanging drop and } \\
\text { implanted in nude rats, rat } \\
\text { brain slices, rBM-based } \\
\text { hydrogel layers or 3-layers } \\
\text { of astrocytes. Hyaluronic } \\
\text { acid was added to media. }\end{array}$ & $\begin{array}{l}\text { Migration on brain slices was through } \\
\text { blood vessels. Spheroids on rBM hydrogel } \\
\text { and astrocyte layers recapitulated some } \\
\text { migratory patterns seen in live rat brains. } \\
\text { Higher HA concentration in media } \\
\text { induced more rapid migration. }\end{array}$ & [15] \\
\hline $\begin{array}{l}\text { Matrix -supported } \\
\text { spheroid }\end{array}$ & GBM cell line U251N & $\begin{array}{l}\text { Hanging drop then } \\
\text { embedded in collagen gel. }\end{array}$ & $\begin{array}{l}\text { TMZ was effective in dose- and } \\
\text { time-dependent manner }\end{array}$ & [1] \\
\hline $\begin{array}{l}\text { Matrix -supported } \\
\text { spheroid }\end{array}$ & $\begin{array}{l}\text { Patient-derived cell } \\
\text { lines K301, GBM6, } \\
\text { GS024 \& GS025 }\end{array}$ & $\begin{array}{l}\text { Tumouroids were formed } \\
\text { in suspension, dissociated, } \\
\text { then transferred to } \\
\text { HA-based hydrogel } \\
\text { in a microfluidic chip. }\end{array}$ & $\begin{array}{l}\text { Higher HA induced proliferation and } \\
\text { drug resistance. }\end{array}$ & [89] \\
\hline $\begin{array}{l}\text { Matrix-supported } \\
\text { tumouroid }\end{array}$ & Patient-derived CSCS. & $\begin{array}{l}\text { Low-attachment plates and } \\
\text { neurobasal media then } \\
\text { encapsulation } \\
\text { in HA/collagen hydrogel. } \\
\text { Interstitial pressure was } \\
\text { applied by deferentially } \\
\text { filling a Millipore insert } \\
\text { in a cell culture well. }\end{array}$ & $\begin{array}{l}\text { Increased flow through the channel } \\
\text { induced patient-specific increase } \\
\text { in migration between } 1.3 \text { and } 1.5 \text {-fold. } \\
\text { With knockdown of CXR4, CXCL12 and } \\
\text { CD } 44 \text {, a flow-induced increase } \\
\text { in migration was neutralised. }\end{array}$ & [70] \\
\hline
\end{tabular}

Regarding molecular considerations, a microfluidic matrix-supported tumouroid model has been used to demonstrate that Interstitial fluid flow (IFF)-induced increases in invasion can be neutralised by blocking a patient-specific combination of CXCR4, CXCL12, and CD44 [70].

These findings suggest that hydrogel cultures that incorporate aspects of brain mechanics and ECM can faithfully recapitulate relevant HGG behaviours. However, these models do not recapitulate the diverse interactions between the cancer cells and the cellladen TME. This could be achieved in part by incorporating a model of the healthy brain in the form of a cerebral organoid.

\section{In-Vitro Models of Healthy Brain}

Organoid cultures are organ-like 3D models generated from HESCs, induced pluripotent stem cells (IPSCS) or adult stem cells (ASCS) [91-93]. Organoids are defined as a self-organised 3D structures comprising multiple cell types with organisation, organ-like function and gene expression indicative of the organ being modelled [94]. Healthy BOs can model healthy brain elements for studying initiation, progression and invasion of HGG.

Table 5 presents a list of organoid models used for GBM research. The formation of organoids is heavily influenced by the microenvironment [23], which encompasses the provision of growth factors, morphogens, cell-cell interactions and cell-matrix interactions. These elicit changes in cell migration, differentiation and proliferation [23]. BOs have been generated from primary ESC and HESC cell lines [11,75], or IPSCS by exposing them to brain-mimetic stiffness cues $[75,91,95]$ or specialised medium regimens $[11,91]$. BOs can be complex and are able to recapitulate the organisation and expression equivalent to a 20-week old human foetal brain [11]. Furthermore, organoids can display a primitive ventricular system, neural rosettes, microvasculature and expression of neural stem cell 
markers [11,96]. Although sophisticated, organoid culture has certain caveats such as an upper size limit imposed by unphysiological hypoxia. This has led to the use of shaking bioreactors [97] and millifluidic systems [98], for example, that improve media exchange to extend that limit [98].

Table 5. Methods for the formation of BOs and the findings generated with their use.

\begin{tabular}{|c|c|c|c|c|}
\hline Model Type & Cell Origin & Culture Method & Findings & Ref \\
\hline Brain organoid & HESC cell line H9 & Differentiation media & $\begin{array}{l}\text { Organoids were transduced to invoke } \\
\text { oncogenesis. } \\
\text { The number of modified, malignant cells } \\
\text { surpassed healthy organoid cells over weeks. }\end{array}$ & [75] \\
\hline Brain organoid & $\begin{array}{l}\text { HESC cell lines H1, H6 } \\
\text { or H9 }\end{array}$ & $\begin{array}{l}\text { Matrigel-coated plates \& } \\
\text { differentiation media }\end{array}$ & $\begin{array}{l}\text { A primitive ventricular system and neural } \\
\text { rosettes were formed \& a proliferative zone of } \\
\text { neural stem cells was present. }\end{array}$ & [11] \\
\hline Brain organoid & IPSCS & $\begin{array}{l}\text { Differentiation media \& } \\
\text { transfer to orbital shaker or } \\
\text { millifluidic device }\end{array}$ & $\begin{array}{l}\text { Millifluidic media exchange successfully } \\
\text { reduced size of necrotic and hypoxic regions. } \\
\text { No overall size difference was observed. }\end{array}$ & [98] \\
\hline Brain organoid & HESCs & $\begin{array}{l}\text { Low-attachment plates \& } \\
\text { differentiation media }\end{array}$ & $\begin{array}{l}\text { Induction of common GBM genes with } \\
\text { electroporation resulted in malignant cells } \\
\text { overtaking healthy organoid cells within } \\
\text { a month. }\end{array}$ & [96] \\
\hline
\end{tabular}

\section{Cerebral Organoid/Glioblastoma Co-Culture}

Co-culture of primary GTs with BOs may be the most sophisticated model available in terms of recapitulation of the cancer environment. See Table 6 for a list of GT/BO or GS/BO co-culture combinations reported in the literature for modelling GBM (no use of PGBM was found). For example, Nayernia et al. co-cultured human pluripotent stem cell (HPSC) line H1-derived cerebral organoids with patient-derived CSCS in neural induction media in low-attachment plates to form free co-cultures. They observed radial invasion of GBM cells into the organoid tissue and increases in ECM-related genes that had a high impact on patient mortality [77]. These complex co-cultures were also produced by colocating organoids and patient-derived CSCS, where tumouroids formed and infiltrated the BOs [11,75]. The extent of infiltration was patient-specific and in some cases, $30 \%$ of the organoid volume was overtaken by GBM after three weeks [75]. Additionally, levels of patient-specific EGFR were retained [11,99], which is rapidly lost when cells are cultured in 2D on stiff tissue culture plastic $[99,100]$.

Others have studied tumour initiation by generating cerebral organoids and inducing oncogenesis with a combination of p53 knockout and transduction with an oncogene (HRasG12V) [75]. This induced oncogenesis [96] and the resulting organoids recapitulated the lethality observed [75]. Furthermore, BO/GT models were discovered to support the formation of TMs [11], which could be key to modelling the most aggressive GBMs and testing related targets, such as GAP-43. When GAP-43 was knocked down in a mouse model of GBM, the therapy-resistant effect of TMS was neutralised [29,47] and invasion and proliferation decreased [47]. Tweeny-homolog 1 (Ttyh1) has also been implicated in the invasiveness of TMs at the tumour leading edge [30], so may also present a viable target. Together, these studies imply that BO/GT co-cultures could be valuable for generating patient-specific models. These co-culture models are complex and time consuming to produce. Modern technologies such as 3D bioprinting may be able to streamline these processes to producing complex co-culture models. 
Table 6. Key methods for the formation of co-culture models from various combinations of tumouroid/spheroid/organoid and the findings generated with their use.

\begin{tabular}{|c|c|c|c|c|c|}
\hline $\begin{array}{l}\text { Cancerous } \\
\text { Constituent }\end{array}$ & Culture Method & $\begin{array}{l}\text { Healthy Brain } \\
\text { Constituent }\end{array}$ & Culture Method & Findings & Ref. \\
\hline Tumouroid & $\begin{array}{l}\text { Dissociated primary } \\
\text { CSCS cultured } \\
\text { in low-attachment } \\
\text { plates with } \\
\text { differentiation media }\end{array}$ & Brain organoid & $\begin{array}{l}\text { HESC cell line H1 } \\
\text { cultured } \\
\text { in low-attachment } \\
\text { plates \& } \\
\text { differentiation media }\end{array}$ & $\begin{array}{l}\text { Radial migration of tumouroid } \\
\text { cells. Modification of ECM } \\
\text { related expression similar to } \\
\text { in-vivo. }\end{array}$ & {$[77]$} \\
\hline Spheroid & $\begin{array}{l}\text { SK2176 GBM cell-line } \\
\text { cultured } \\
\text { in low-attachment } \\
\text { plates }\end{array}$ & Brain organoid & $\begin{array}{l}\text { HESC cell line H1 } \\
\text { cultured } \\
\text { in differentiation } \\
\text { media }\end{array}$ & $\begin{array}{l}\text { Spontaneous attachment and } \\
\text { invasion of tumour cells into } \\
\text { cerebral organoid. } 30 \% \text { of } \\
\text { organoid volume was invaded } \\
\text { after } 24 \text { days. } \\
\text { Degree of invasiveness in model } \\
\text { correlated with lethality of } \\
\text { orthotopically xenografted } \\
\text { tumouroids. }\end{array}$ & {$[75]$} \\
\hline $\begin{array}{l}\text { GSC cell line } \\
\text { in suspension }\end{array}$ & Co-culture & Brain organoid & $\begin{array}{l}\text { HESC cell line H1, } \\
\text { H6 or H9 culture } \\
\text { in Matrigel-coated } \\
\text { plates with } \\
\text { differentiation media }\end{array}$ & $\begin{array}{l}\text { Co-cultures were more resistant } \\
\text { to chemo-therapeutic agents } \\
\text { and radiation versus 2D } \\
\text { cultures. } \\
\text { EGFR levels of parent tissue } \\
\text { were recapitulated in 3D } \\
\text { co-cultures and absent in 2D } \\
\text { analogues. }\end{array}$ & {$[11]$} \\
\hline $\begin{array}{l}\text { Transfection of } \\
18 \text { GBM-like } \\
\text { gene mutations / } \\
\text { amplifications }\end{array}$ & $\begin{array}{l}\text { Oncogenesis of } \\
\text { organoid via } \\
\text { electroporation }\end{array}$ & $\begin{array}{l}\text { Cerebral } \\
\text { organoid }\end{array}$ & $\begin{array}{l}\text { Generated from EBs } \\
\text { with differentiation } \\
\text { media }\end{array}$ & $\begin{array}{l}\text { GBM can be initiated by } \\
\text { selective gene manipulation. } \\
\text { Increased invasiveness, higher } \\
\text { expression of invasion-related } \\
\text { genes and lower expression of } \\
\text { tumour-inhibitive genes were } \\
\text { observed in gene-altered cells. }\end{array}$ & [96] \\
\hline
\end{tabular}

\section{Bioprinted Organoid/Tumouroid Models of High-Grade Glioma}

Bioprinting is a form of matrix-supported cell culture where a specialised 3D printer is used to deposit cell-laden bioinks onto a printing bed, the two most common approaches being extrusion (filament) or ink-jet (droplet) approaches [86] - see Figure 2 for a graphical representation of each. Ink-jet printing is a no-contact option where droplets of bioink are released from a nozzle by applying heat or electric current [101] and can even be done with a modified office printer [102]. Extrusion printing is done by applying pressure-either pneumatically or with a piston-to a reservoir of bioink, thereby forcing it through a nozzle. The nozzle can then be manipulated using a CAD file to produce specially-controlled patterns of bioink [101]. An alternative to these more common printer types, a LASERbased printing method called LASER-based direct writing, can manipulate single cells and place them individually [103]. The more specialised systems for bioprinting have been reviewed elsewhere [104,105].

Bioinks are hydrogels that contain living single cells or cell conglomerates (spheroids or tumouroids). Laying down gel constructs in an additive way using 3D printing offers an unprecedented level of control over the spatial distribution of various cell/gel combinations [2]. The first bioprinted cell/hydrogel constructs were fabricated with a gelatine/alginate/fibrin bioink laden with HeLa cells [106]. Bioinks laden with GBM cells have since been developed from collagen alone [107], or in combination with alginate [2], gelatine methacrylate (GELMA) $[48,108]$ or HA $[109,110]$. Decellularised animal brain ECM can also be formed into an ink $[2,110,111]$, as well as a host of synthetic polymers 
including polyethylene glycol (PEG) [112]. Table 7 presents a list of studies that utilise bioprinting of GBM-laden bioinks.
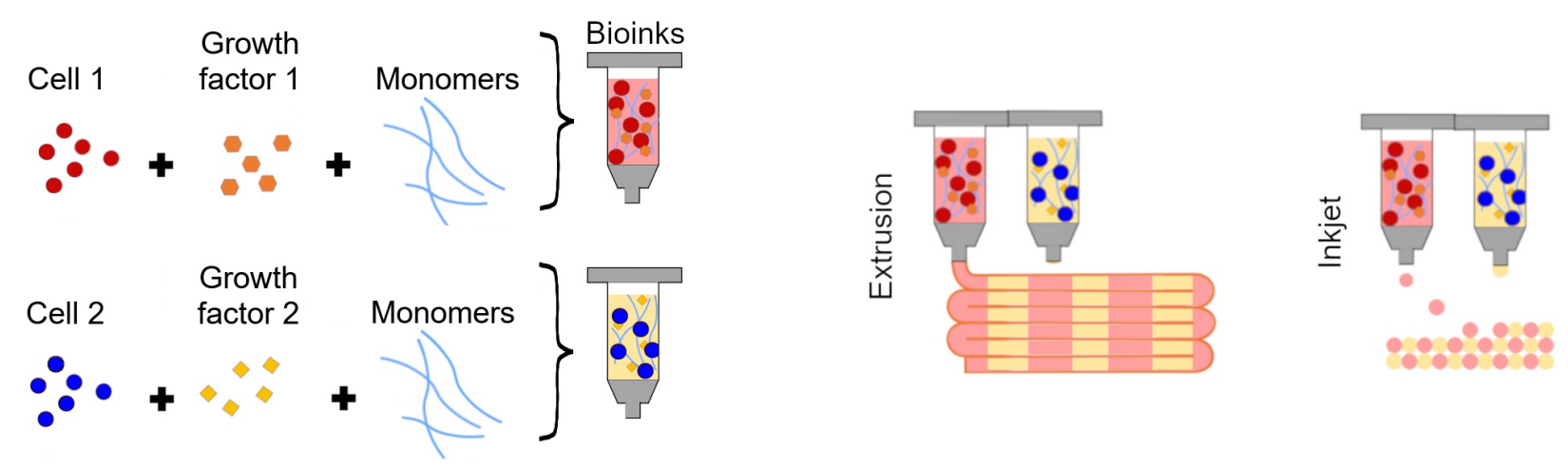

Figure 2. A schematic representation of co-printed disease models with two distinct gel formulations arranged spatially with filament- and droplet-style bioprinting.

Table 7. Key findings reported with the use of bioprinted glioblastoma models. No bioprinted paediatric GBM models were found at the time of writing.

\begin{tabular}{llll}
\hline Model Type & Cells Used & $\begin{array}{l}\text { Gel Material and } \\
\text { Organisation }\end{array}$ & Findings \\
\hline $\begin{array}{l}\text { Bioprinted matrix } \\
\text {-supported } \\
\text { co-culture }\end{array}$ & $\begin{array}{l}\text { GBM cell line U87MG, } \\
\text { GSC lines G166, G144 \& } \\
\text { G7 monocyte cell line } \\
\text { MM6 }\end{array}$ & $\begin{array}{l}<50 \text { mg/L HA or } \\
\text { collagen I. Central } \\
\text { tumouroid was printed } \\
\text { then surrounded by } \\
\text { a stroma-like cell-laden gel } \\
\text { construct. }\end{array}$ & $\begin{array}{l}\text { Printed GBM cells remained viable (>90\%) } \\
\text { for months and CSCS retained stemness. } \\
\text { spheroids compared to 2D co-cultures. } \\
\text { GBM cells printed alongside fibroblasts } \\
\text { were more resistant to TMZ. }\end{array}$ \\
$\begin{array}{llll}\text { Bioprinted matrix } \\
\text {-supported } \\
\text { co-culture }\end{array}$ & $\begin{array}{l}\text { GELMA was used as both } \\
\text { GBM cell line GL261 \& }\end{array}$ & $\begin{array}{l}\text { GBM and stroma-like } \\
\text { bioink to create a GBM } \\
\text { tumour model enclosed by } \\
\text { a macrophage-laden gel } \\
\text { RAW264.7 cell line }\end{array}$ & $\begin{array}{l}\text { Shear-thinning GELMA decreased } \\
\text { printing-related cell death. Macrophages } \\
\text { migrated towards GBM cells in co-culture } \\
\text { and GBM cells had 15-fold increases } \\
\text { in GBM-specific markers compared to 3D } \\
\text { and 2D mono-culture. }\end{array}$ \\
\hline
\end{tabular}

\subsection{Addition of Stromal Components to 3D Bioprinted High-Grade Glioma Models}

Of the environments in the tumour stroma, an advantageous one to model is the vasculature, through which therapies are delivered. Alternatively to bioprinting, a model of vasculature can be generated through self-organisation of stem cells [11], coating organoids in endothelial cell-laden Matrigel [113] and through passive angiogenesis in the host (mouse) [114].

Multiple cell types have been bioprinted to form more complex systems with characteristics indicative of brain $[2,48,107,111]$. Models of vasculature can also be incorporated $[67,96,97,115]$. Even more importantly for GBM research is a 3D model for the bloodbrain barrier (BBB), which can be done using complex microfluidics [116]. Table 8 contains details of several microfluidic vessel models for GBM that represent this emerging trend. A microfluidic channel within a collagen/laminin hydrogel lined with human umbilical vascular endothelial cells (HUVECS) serves as a vessel model [107]. Primary GSs injected a distance from this microvessel model migrated towards the microfluidic vessel at an increasing speed with increasing laminin concentration within the encapsulating bioink [107]. Demonstrating the validity of this model, the total distance migrated and TMZ response were patient-specific. The same cells cultured in 2D failed to exhibit patient-specific responses [107]. 
Table 8. Engineered organoid models of GBM incorporating a vasculature model.

\begin{tabular}{|c|c|c|c|}
\hline Model Type & Gel Material and Layout & Findings & Ref. \\
\hline $\begin{array}{l}\text { 3D GBM- vascular niche with } \\
\text { patient- derived CSCS } \\
\text { co-cultured with HUVECs }\end{array}$ & $\begin{array}{l}\text { A straight fluidic vascular channel } \\
\text { was printed with collagen I and } \\
\text { lined with HUVECS. } \\
\text { CSCS were seeded adjacent to } \\
\text { the microvessel. }\end{array}$ & $\begin{array}{l}\text { At the highest concentration of laminin } \\
(100 \mu \mathrm{g} / \mathrm{mL}), C S C s \text { migrated } 1.5 \times \text { further than } \\
\text { in the gel containing } 10 \mu \mathrm{g} / \mathrm{mL} \text { of laminin. }\end{array}$ & [107] \\
\hline $\begin{array}{l}\text { GBM-on-a- chip with } \\
\text { continuous cell line U-87 and } \\
\text { patient- derived line } \\
\text { co-cultured with HUVECs }\end{array}$ & $\begin{array}{l}\text { A circular fluidic vascular channel } \\
\text { was printed in collagen and } \\
\text { a bioink developed from } \\
\text { decellularised porcine brain ECM. } \\
\text { GBM-laden hydrogel was printed } \\
\text { in the centre of a ring of collagen } \\
\text { gel containing HUVECs. This was } \\
\text { surrounded again by } \\
\text { a microchannel with an outer } \\
\text { boundary printed in gas permeable } \\
\text { silicone. }\end{array}$ & $\begin{array}{l}\text { GBM cells grew in dense spheres with } \\
\text { an anoxia-normoxia gradient and peripheral } \\
\text { pseudopalisading cells. Cells in the intermediate } \\
\text { region excreted factors leading to microvessel } \\
\text { formation in the periphery. } \\
\text { In porcine brain-derived gel, angiogenesis, } \\
\text { proliferation and expression of pro-angiogenic } \\
\text { genes and ECM remodelling proteins increased. } \\
\text { All patient-derived cells in co-culture with } \\
\text { HUVECs exhibited a dose-dependent response } \\
\text { to TMZ but those on-chip recapitulated clinical } \\
\text { therapy resistance, unlike the same cells cultured } \\
\text { in } 2 \mathrm{D} \text { and 3D monoculture. Following multiple } \\
\text { treatments, GBM cells extracted from patients } \\
\text { with a longer survival exhibited decreased } \\
\text { metabolic activity even after treatment ceased, } \\
\text { whereas the metabolic activity increased after } \\
\text { treatment ceased in the cells originating from } \\
\text { patients with a shorter survival. }\end{array}$ & [111] \\
\hline
\end{tabular}

Vasculature has also been generated in a healthy BOs by coating with a Matrigel/ HUVEC layer. The HUVECS infiltrated the organoid and developed vasculature [113]. Co-culture of GBM cells with monocytes [2], macrophages [2,111] and astrocytes [108] have also been reported in 3D bioprinted models in order to model a simplified immune response.

GS co-cultures can be bioprinted with high viability $[48,111,117]$ and retention of stemness [117]. However, since bioprinting is fairly new, new drug targets have yet to be discovered using bioprinted models. They have, however, along with microfluidic systems, potential to be valuable drug screening tools for GBM $[78,118,119]$. While currently there are no reports of bioprinted PGBM, such models are likely to be equally valuable in the study of PGBM.

\subsection{Future Trends in 3D Bioprinting}

The 3D bioprinting community has been moving towards rapid creation of complex multi-cell and multi-gel constructs that model increasingly complex structures. Bioprinting a wider variety of cell types in an ever-increasing library of structures is driven by developments in the printing technology itself-by adding the ability to print multiple materials $[115,120]$ — as well as the development of increasingly advanced biomaterials with synthetic as well as animal-derived constituents [121] to accommodate primary cells in appropriately tailored environments. Additionally, some groups are producing $4 \mathrm{D}$ biomaterials, so that the degradation of the crosslinked polymer can be controlled over time via light [122] or temperature [123], or the cells influenced by an electrically conductive polymer [124].

Additionally, alongside developments in microvessels-mimicking [115], there has also been recent development in cancer-on-a-chip systems $[111,119,125]$. While these microfluidic chips are not necessarily bioprinted, they offer various degrees of functionality afforded by the versatility of microfluidics. Advanced cancer-on-a-chip systems have been used to recapitulate response to chemoradiotherapy [111] and are especially suited 
to investigating mechanisms of response to fluid shear [70,126], for example. Threedimensional GS-on-a-chip systems are already a reality and they exhibit hypoxia and related increases in stem cell markers [127].

\title{
7. Conclusions and Future Outlook
}

Unfortunately, even given these advances in methods and technology, there are a distinct lack of advanced models of PHGG compared to adult HGG. As discussed, tools are available for the production of high quality patient-specific HGG models on a time scale relevant for patients even with the most dire prognosis. Advanced bioengineered models of GBM are rapidly progressing and there is no doubt that they can make a real impact on the outcomes of patients. These models will be necessary to undertake high-throughput screening to test for potential new therapeutic agents.

In this review, comparisons have been made between various effective culture modalities used to incorporate important aspects of the TME into pre-clinical models of GBM and PGBM. As is clear, traditional methods are being upgraded to complex hybrid techniques that incorporate combinations of controlled extracellular matrix composition, mechanical properties, fluid properties, cell-stroma interactions and solute concentrations, among others. These are being effectively utilised to gain insight into the complex mechanisms behind GBM. Notably, the combination of bioprinting and microfluidics has great potential to facilitate the co-culture of tumour, stem and stromal cells in a controlled, dynamic TME that elicits behaviours increasingly true to the patient's own tissues.

There are certainly still many unanswered questions about PHGG. Moreover, of the work published on PubMed since the first mention of pre-clinical models of GBM in 1969, the total number of those mentioning PGBM comprise only $4.5 \%$; there is a need for researchers to first take up the use of available PHGG cell lines [90] so that progress can then be made in the areas of tumouroids, co-culture and complex 3D engineered models (bioprinted and microfluidic alike). There is substantial progress to be made in this area, and once it is, steps can be taken to make all HGGs less of a burden.

Author Contributions: Conceptualization, L.O.-F. and G.O.; writing-original draft preparation, L.O.F. and S.B.; writing-review and editing, L.O.-F., S.B., R.U., M.E., D.G. and G.O.; visualization, L.O.-F. and S.B.; supervision, G.O.; project administration, G.O.; funding acquisition, G.O. All authors have read and agreed to the published version of the manuscript.

Funding: This research was funded by The Kids Cancer Project grant, Perpetual Impact philanthropy grant and the Balance Foundation.

Institutional Review Board Statement: Not applicable.

Informed Consent Statement: Not applicable.

Data Availability Statement: Not applicable.

Conflicts of Interest: The authors declare no conflict of interest.

\author{
Abbreviations \\ The following abbreviations are used in this manuscript: \\ 2D \\ Three-dimensional (3D) \\ ASCS \\ AUKRA \\ $\mathrm{BBB}$ \\ CSCS \\ ECM \\ EGFR \\ GA-MSCS \\ GAGs \\ Two-dimensional \\ Three-dimensional \\ Adult stem cells \\ Aurora A kinase \\ Blood-brain barrier \\ Cancer stem cells \\ Extracellular matrix \\ Epidermal growth factor receptor \\ Glioma associated mesenchymal stem cells \\ Glycosaminoglycans
}




$\begin{array}{ll}\text { GBM } & \text { Glioblastoma } \\ \text { GELMA } & \text { Gelatine methacrylate } \\ \text { GICS } & \text { Glioma initiating cells } \\ \text { GSCS } & \text { Glioma stem cells } \\ \text { HA } & \text { Hyaluronic acid } \\ \text { HESC } & \text { Human embryonic stem cell } \\ \text { HGG } & \text { High-grade glioma } \\ \text { HIFS } & \text { Hypoxia inducible factors } \\ \text { HUVECS } & \text { Human umbilical vascular endothelial cells } \\ \text { IFF } & \text { Interstitial fluid flow } \\ \text { IPSCS } & \text { Induced pluripotent stem cells } \\ \text { MMRE } & \text { Multifrequency MRE } \\ \text { MRI } & \text { Magnetic resonance imaging } \\ \text { NAWM } & \text { Normal-appearing white matter } \\ \text { OPCS } & \text { Oligodendroglial precursor cells } \\ \text { PDX } & \text { Patient-derived xenograft } \\ \text { PEG } & \text { Polyethylene glycol } \\ \text { PGBM } & \text { Paediatric GBM } \\ \text { RBM } & \text { Reconstituted basement membrane } \\ \text { RCCS } & \text { Rotary cell culture system } \\ \text { TME } & \text { Tumour microenvironment } \\ \text { TMS } & \text { Tumour microtubules } \\ \text { TMZ } & \text { Temozolomide } \\ & \end{array}$

\section{References}

1. Zhang, I.; Beus, M.; Stochaj, U.; Le, P.U.; Zorc, B.; Rajić, Z.; Petrecca, K.; Maysinger, D. Inhibition of Glioblastoma Cell Proliferation, Invasion, and Mechanism of Action of a Novel Hydroxamic Acid Hybrid Molecule. Cell Death Discov. 2018, 4, 1-14. [CrossRef] [PubMed]

2. Hermida, M.A.; Kumar, J.D.; Schwarz, D.; Laverty, K.G.; Di Bartolo, A.; Ardron, M.; Bogomolnijs, M.; Clavreul, A.; Brennan, P.M.; Wiegand, U.K.; et al. Three Dimensional in Vitro Models of Cancer: Bioprinting Multilineage Glioblastoma Models. Adv. Biol. Regul. 2020, 75, 100658. [CrossRef] [PubMed]

3. Jacob, F.; Salinas, R.D.; Zhang, D.Y.; Nguyen, P.T.; Schnoll, J.G.; Wong, S.Z.H.; Thokala, R.; Sheikh, S.; Saxena, D.; Prokop, S.; et al. A Patient-Derived Glioblastoma Organoid Model and Biobank Recapitulates Inter- and Intra-Tumoral Heterogeneity. Cell 2020, 180, 188-204. [CrossRef] [PubMed]

4. Freeman, C.R.; Farmer, J.P. Pediatric Brain Stem Gliomas: A Review. Int. J. Radiat. Oncol. Biol. Phys. 1998, 40, $265-271$. [CrossRef]

5. Hargrave, D.; Bartels, U.; Bouffet, E. Diffuse Brainstem Glioma in Children: Critical Review of Clinical Trials. Lancet Oncol. 2006, 7, 241-248. [CrossRef]

6. Janssens, G.O.; Gidding, C.E.; Van Lindert, E.J.; Oldenburger, F.R.; Erasmus, C.E.; Schouten-Meeteren, A.Y.; Kaanders, J.H. The role of Hypofractionation Radiotherapy for Diffuse Intrinsic Brainstem Glioma in Children: A Pilot Study. Int. J. Radiat. Oncol. Biol. Phys. 2009, 73, 722-726. [CrossRef]

7. Vanan, M.I.; Eisenstat, D.D. Management of High-grade Gliomas in the Pediatric Patient: Past, Present, and Future. Neuro-Oncol. Pract. 2014, 1, 145-157. [CrossRef]

8. Fangusaro, J.; Warren, K.E. Unclear Standard of Care for Pediatric High Grade Glioma Patients. J. Neuro-Oncol. 2013, 113, 341-342. [CrossRef] [PubMed]

9. Cohen, K.J.; Pollack, I.F.; Zhou, T.; Buxton, A.; Holmes, E.J.; Burger, P.C.; Brat, D.J.; Rosenblum, M.K.; Hamilton, R.L.; Lavey, R.S.; et al. Temozolomide in the Treatment of High-grade Gliomas in Children: A Report from the Children's Oncology Group. Neuro-Oncology 2011, 13, 317-323. [CrossRef]

10. Jansen, M.; Van Vuurden, D.; Vandertop, W.; Kaspers, G. Diffuse Intrinsic Pontine Gliomas: A Systematic Update on Clinical Trials and Biology. Cancer Treat. Rev. 2012, 38, 27-35. [CrossRef]

11. Linkous, A.; Balamatsias, D.; Snuderl, M.; Edwards, L.; Miyaguchi, K.; Milner, T.; Reich, B.; Cohen-Gould, L.; Storaska, A.; Nakayama, Y.; et al. Modeling Patient-Derived Glioblastoma with Cerebral Organoids. Cell Rep. 2019, 26, 3203-3211. [CrossRef] [PubMed]

12. Farrell, K.; Mahajan, G.; Srinivasan, P.; Lee, M.Y.; Kothapalli, C.R. Pediatric Glioblastoma Cells Inhibit Neurogenesis and Promote Astrogenesis, Phenotypic Transformation and Migration of Human Neural Progenitor Cells Within Cocultures. Exp. Cell Res. 2018, 362, 159-171. [CrossRef] 
13. Martínez-Vélez, N.; Garcia-Moure, M.; Marigil, M.; González-Huarriz, M.; Puigdelloses, M.; Pérez-Larraya, J.G.; Zalacaín, M.; Marrodán, L.; Varela-Guruceaga, M.; Laspidea, V.; et al. The Oncolytic Virus Delta-24-RGD Elicits an Antitumor Effect in Pediatric Glioma and DIPG Mouse Models. Nat. Commun. 2019, 10, 2235. [CrossRef]

14. Gritsenko, P.G.; Ilina, O.; Friedl, P. Interstitial Guidance of Cancer Invasion. J. Pathol. 2012, 226, 185-199. [CrossRef] [PubMed]

15. Gritsenko, P.; Leenders, W.; Friedl, P. Recapitulating -like Plasticity of Glioma Cell Invasion Along Blood Vessels and in Astrocyte-rich Stroma. Histochem. Cell Biol. 2017, 148, 395-406. [CrossRef] [PubMed]

16. Osswald, M.; Jung, E.; Sahm, F.; Solecki, G.; Venkataramani, V.; Blaes, J.; Weil, S.; Horstmann, H.; Wiestler, B.; Syed, M.; et al. Brain Tumour Cells Interconnect to a Functional and Resistant Network. Nature 2015, 528, 93-98. [CrossRef]

17. Gritsenko, P.G.; Atlasy, N.; Dieteren, C.E.; Navis, A.C.; Venhuizen, J.H.; Veelken, C.; Schubert, D.; Acker-Palmer, A.; Westerman, B.A.; Wurdinger, T.; et al. p120-catenin-dependent Collective Brain Infiltration by Glioma Cell Networks. Nat. Cell Biol. 2020, 22, 97-107. [CrossRef]

18. Goranci-Buzhala, G.; Mariappan, A.; Gabriel, E.; Ramani, A.; Ricci-Vitiani, L.; Buccarelli, M.; D’Alessandris, Q.G.; Pallini, R.; Gopalakrishnan, J. Rapid and Efficient Invasion Assay of Glioblastoma in Human Brain Organoids. Cell Rep. 2020, $31,107738$. [CrossRef] [PubMed]

19. Caretti, V.; Zondervan, I.; Meijer, D.H.; Idema, S.; Vos, W.; Hamans, B.; Bugiani, M.; Hulleman, E.; Wesseling, P.; Vandertop, W.P.; et al. Monitoring of Tumor Growth and Post-irradiation Recurrence in a Diffuse Intrinsic Pontine Glioma Mouse Model. Brain Pathol. 2011, 21, 441-451. [CrossRef]

20. Vinci, M.; Burford, A.; Molinari, V.; Kessler, K.; Popov, S.; Clarke, M.; Taylor, K.R.; Pemberton, H.N.; Lord, C.J.; Gutteridge, A.; et al. Functional Diversity and Cooperativity Between Subclonal Populations of Pediatric Glioblastoma and Diffuse Intrinsic Pontine Glioma Cells. Nat. Med. 2018, 24, 1204-1215. [CrossRef]

21. Bhaduri, A.; Di Lullo, E.; Jung, D.; Müller, S.; Crouch, E.E.; Espinosa, C.S.; Ozawa, T.; Alvarado, B.; Spatazza, J.; Cadwell, C.R.; et al. Outer Radial Glia-like Cancer Stem Cells Contribute to Heterogeneity of Glioblastoma. Cell Stem Cell 2020, 26, 48-63. [CrossRef] [PubMed]

22. Tanaka, S.; Louis, D.N.; Curry, W.T.; Batchelor, T.T.; Dietrich, J. Diagnostic and Therapeutic Avenues for Glioblastoma: No Longer a Dead End? Nat. Rev. Clin. Oncol. 2013, 10, 14. [CrossRef]

23. Bayir, E.; Sendemir, A.; Missirlis, Y.F. Mechanobiology of Cells and Cell Systems, Such as Organoids. Biophys. Rev. 2019, 11, 721-728. [CrossRef]

24. Hoffman, M.; Gillmor, A.H.; Kunz, D.J.; Johnston, M.J.; Nikolic, A.; Narta, K.; Zarrei, M.; King, J.; Ellestad, K.; Dang, N.H.; et al. Intratumoral Genetic and Functional Heterogeneity in Pediatric Glioblastoma. Cancer Res. 2019, 79, 2111-2123. [CrossRef] [PubMed]

25. Dobson, T.H.; Gopalakrishnan, V. Preclinical Models of Pediatric Brain Tumors—Forging Ahead. Bioengineering 2018,5 , 81. [CrossRef]

26. Figueroa, J.; Phillips, L.M.; Shahar, T.; Hossain, A.; Gumin, J.; Kim, H.; Bean, A.J.; Calin, G.A.; Fueyo, J.; Walters, E.T.; et al. Exosomes from Glioma-Associated Mesenchymal Stem Cells Increase the Tumorigenicity of Glioma Stem-Like Cells via Transfer of miR-1587. Cancer Res. 2017, 77, 5808-5819. [CrossRef]

27. Hossain, A.; Gumin, J.; Gao, F.; Figueroa, J.; Shinojima, N.; Takezaki, T.; Priebe, W.; Villarreal, D.; Kang, S.G.; Joyce, C.; et al. Mesenchymal Stem Cells Isolated from Human Gliomas Increase Proliferation and Maintain Stemness of Glioma Stem Cells Through the IL-6/gp130/STAT3 Pathway. Stem Cells 2015, 33, 2400-2415. [CrossRef]

28. Gillespie, S.; Monje, M. An Active Role for Neurons in Glioma Progression: Making Sense of Scherer's structures. Neuro-Oncology 2018, 20, 1292-1299. [CrossRef]

29. Osswald, M.; Solecki, G.; Wick, W.; Winkler, F. A Malignant Cellular Network in Gliomas: Potential Clinical Implications. Neuro-Oncology 2016, 18, 479-485. [CrossRef] [PubMed]

30. Osswald, M.; Jung, E.; Wick, W.; Winkler, F. Tunneling Nanotube-Like Structures in Brain Tumors. Cancer Rep. 2019 , 2 , e1181. [CrossRef]

31. Singh, S.K.; Hawkins, C.; Clarke, I.D.; Squire, J.A.; Bayani, J.; Hide, T.; Henkelman, R.M.; Cusimano, M.D.; Dirks, P.B. Identification of Human Brain Tumour Initiating Cells. Nature 2004, 432, 396-401. [CrossRef]

32. Hubert, C.G.; Rivera, M.; Spangler, L.C.; Wu, Q.; Mack, S.C.; Prager, B.C.; Couce, M.; McLendon, R.E.; Sloan, A.E.; Rich, J.N. A Three-dimensional Organoid Culture System Derived from Human Glioblastomas Recapitulates the Hypoxic Gradients and Cancer Stem Cell Heterogeneity of Tumors Found. Cancer Res. 2016, 76, 2465-2477. [CrossRef]

33. Wenger, A.; Larsson, S.; Danielsson, A.; Elbæk, K.J.; Kettunen, P.; Tisell, M.; Sabel, M.; Lannering, B.; Nordborg, C.; Schepke, E.; et al. Stem Cell Cultures Derived from Pediatric Brain Tumors Accurately Model the Originating Tumors. Oncotarget 2017, 8, 18626. [CrossRef] [PubMed]

34. Aziz-Bose, R.; Monje, M. Diffuse Intrinsic Pontine Glioma: Molecular Landscape and Emerging Therapeutic Targets. Curr. Opin. Oncol. 2019, 31, 522-530. [CrossRef]

35. Surowiec, R.K.; Ferris, S.F.; Apfelbaum, A.; Espinoza, C.; Mehta, R.K.; Monchamp, K.; Sirihorachai, V.R.; Bedi, K.; Ljungman, M.; Galban, S. Transcriptomic Analysis of Diffuse Intrinsic Pontine Glioma (DIPG) Identifies a Targetable ALDH-positive Subset of Highly Tumorigenic Cancer Stem-like Cells. Mol. Cancer Res. 2020, 19, 223-239. [CrossRef]

36. Jung, E.; Alfonso, J.; Osswald, M.; Monyer, H.; Wick, W.; Winkler, F. Emerging Intersections Between Neuroscience and Glioma Biology. Nat. Neurosci. 2019, 22, 1951-1960. [CrossRef] [PubMed] 
37. Agnihotri, S.; Burrell, K.; Buczkowicz, P.; Remke, M.; Golbourn, B.; Chornenkyy, Y.; Gajadhar, A.; Fernandez, N.A.; Clarke, I.D.; Barszczyk, M.S.; et al. ATM Regulates 3-Methylpurine-DNA Glycosylase and Promotes Therapeutic Resistance to Alkylating Agents. Cancer Discov. 2014, 4, 1198-1213. [CrossRef]

38. Martínez-Ramos, C.; Lebourg, M. Three-Dimensional Constructs Using Hyaluronan Cell Carrier as a Tool for the Study of Cancer stem Cells. J. Biomed. Mater. Res. Part B Appl. Biomater. 2015, 103, 1249-1257. [CrossRef]

39. Rath, B.H.; Wahba, A.; Camphausen, K.; Tofilon, P.J. Coculture with Astrocytes Reduces the Radiosensitivity of Glioblastoma Stem-like Cells and Identifies Additional Targets for Radiosensitization. Cancer Med. 2015, 4, 1705-1716. [CrossRef]

40. Vartanian, A.; Singh, S.K.; Agnihotri, S.; Jalali, S.; Burrell, K.; Aldape, K.D.; Zadeh, G. GBM's Multifaceted Landscape: Highlighting Regional and Microenvironmental Heterogeneity. Neuro-Oncology 2014, 16, 1167-1175. [CrossRef] [PubMed]

41. Mudassar, F.; Shen, H.; O’Neill, G.; Hau, E. Targeting Tumor Hypoxia and Mitochondrial Metabolism with Anti-parasitic Drugs to ImproveRadiation Response in High-grade Gliomas. J. Exp. Clin. Cancer Res. 2020, 39, 1-17. [CrossRef]

42. Blandin, A.F.; Durand, A.; Litzler, M.; Tripp, A.; Guérin, É.; Ruhland, E.; Obrecht, A.; Keime, C.; Fuchs, Q.; Reita, D.; et al. Hypoxic Environment and Paired Hierarchical 3D and 2D Models of Pediatric H3. 3-mutated Gliomas Recreate the Patient Tumor Complexity. Cancers 2019, 11, 1875. [CrossRef]

43. Yeom, K.W.; Lober, R.M.; Nelson, M.D.; Panigrahy, A.; Blüml, S. Citrate Concentrations Increase with Hypoperfusion in Pediatric Diffuse Intrinsic Pontine Glioma. J. Neuro-Oncol. 2015, 122, 383-389. [CrossRef]

44. Xiao, W.; Sohrabi, A.; Seidlits, S.K. Integrating the Glioblastoma Microenvironment into Engineered Experimental Models. Future Sci. OA 2017, 3, FSO189. [CrossRef] [PubMed]

45. Kim, Y.; Kumar, S. CD44-Mediated Adhesion to Hyaluronic Acid Contributes to Mechanosensing and Invasive Motility. Mol. Cancer Res. 2014, 12, 1416-1429. [CrossRef]

46. Wolf, K.J.; Chen, J.; Coombes, J.D.; Aghi, M.K.; Kumar, S. Dissecting and Rebuilding the Glioblastoma Microenvironment with Engineered Materials. Nat. Rev. Mater. 2019, 4, 651-668. [CrossRef]

47. Xiao, W.; Zhang, R.; Sohrabi, A.; Ehsanipour, A.; Sun, S.; Liang, J.; Walthers, C.M.; Ta, L.; Nathanson, D.A.; Seidlits, S.K. Brain-mimetic 3D Culture Platforms Allow Investigation of Cooperative Effects of Extracellular Matrix Features on Therapeutic Resistance in Glioblastoma. Cancer Res. 2018, 78, 1358-1370. [CrossRef] [PubMed]

48. Heinrich, M.A.; Bansal, R.; Lammers, T.; Zhang, Y.S.; Michel Schiffelers, R.; Prakash, J. Three Dimensional Bioprinted Mini-Brain: A Glioblastoma Model to Study Cellular Interactions and Therapeutics. Adv. Mater. 2019, 31, 1806590. [CrossRef] [PubMed]

49. Venkatesh, H.S.; Morishita, W.; Geraghty, A.C.; Silverbush, D.; Gillespie, S.M.; Arzt, M.; Tam, L.T.; Espenel, C.; Ponnuswami, A.; Ni, L.; et al. Electrical and Synaptic Integration of Glioma into Neural Circuits. Nature 2019, 573, 539-545. [CrossRef]

50. Franze, K. The Mechanical Control of Nervous System Development. Development 2013, 140, 3069-3077. [CrossRef]

51. Bouchonville, N.; Meyer, M.; Gaude, C.; Gay, E.; Ratel, D.; Nicolas, A. AFM Mapping of the Elastic Properties of Brain Tissue Reveals kPa $\mu \mathrm{m}-1$ Gradients of Rigidity. Soft Matter 2016, 12, 6232-6239. [CrossRef]

52. MacManus, D.B.; Pierrat, B.; Murphy, J.G.; Gilchrist, M.D. Region and Species Dependent Mechanical Properties of Adolescent and Young Adult Brain Tissue. Sci. Rep. 2017, 7, 13729. [CrossRef] [PubMed]

53. Northcott, J.M.; Dean, I.S.; Mouw, J.K.; Weaver, V.M. Feeling Stress: The Mechanics of Cancer Progression and Aggression. Front. Cell Dev. Biol. 2018, 6, 17. [CrossRef]

54. Streitberger, K.J.; Lilaj, L.; Schrank, F.; Braun, J.; Hoffmann, K.T.; Reiss-Zimmermann, M.; Käs, J.A.; Sack, I. How Tissue Fluidity Influences Brain Tumor Progression. Proc. Natl. Acad. Sci. USA 2020, 117, 128-134. [CrossRef] [PubMed]

55. Jugé, L.; Petiet, A.; Lambert, S.A.; Nicole, P.; Chatelin, S.; Vilgrain, V.; Van Beers, B.E.; Bilston, L.E.; Sinkus, R. Microvasculature Alters the Dispersion Properties of Shear Waves-A Multi-Frequency MR Elastography Study. NMR Biomed. 2015, 28, $1763-1771$. [CrossRef]

56. Green, M.A.; Bilston, L.E.; Sinkus, R. In Vivo Brain Viscoelastic Properties Measured by Magnetic Resonance Elastography. NMR Biomed. Int. J. Devoted Dev. Appl. Magn. Reson. Vivo 2008, 21, 755-764.

57. Bunevicius, A.; Schregel, K.; Sinkus, R.; Golby, A.; Patz, S. MR elastography of brain tumors. NeuroImage Clin. 2020, 25, 102109. [CrossRef]

58. Venkatesh, S.K.; Yin, M.; Ehman, R.L. Magnetic Resonance Elastography of Liver: Technique, Analysis, and Clinical Applications. J. Magn. Reson. Imaging 2013, 37, 544-555. [CrossRef]

59. Sack, I.; Beierbach, B.; Wuerfel, J.; Klatt, D.; Hamhaber, U.; Papazoglou, S.; Martus, P.; Braun, J. The Impact of Aging and Gender on Brain Viscoelasticity. Neuroimage 2009, 46, 652-657. [CrossRef] [PubMed]

60. Simon, M.; Guo, J.; Papazoglou, S.; Scholand-Engler, H.; Erdmann, C.; Melchert, U.; Bonsanto, M.; Braun, J.; Petersen, D.; Sack, I.; et al. Non-invasive Characterization of Intracranial Tumors by Magnetic Resonance Elastography. New J. Phys. 2013, 15, 085024. [CrossRef]

61. Reiss-Zimmermann, M.; Streitberger, K.J.; Sack, I.; Braun, J.; Arlt, F.; Fritzsch, D.; Hoffmann, K.T. High Resolution Imaging of Viscoelastic Properties of Intracranial Tumours by Multi-Frequency Magnetic Resonance Elastography. Clin. Neuroradiol. 2015, 25, 371-378. [CrossRef]

62. Sakai, N.; Takehara, Y.; Yamashita, S.; Ohishi, N.; Kawaji, H.; Sameshima, T.; Baba, S.; Sakahara, H.; Namba, H. Shear Stiffness of 4 Common Intracranial Tumors Measured Using MR Elastography: Comparison with Intraoperative Consistency Grading. Am. J. Neuroradiol. 2016, 37, 1851-1859. [CrossRef] 
63. Pepin, K.M.; McGee, K.P.; Arani, A.; Lake, D.S.; Glaser, K.J.; Manduca, A.; Parney, I.F.; Ehman, R.L.; Huston, J. MR Elastography Analysis of Glioma Stiffness and IDH1-Mutation Status. Am. J. Neuroradiol. 2018, 39, 31-36. [CrossRef]

64. Hughes, J.D.; Fattahi, N.; Van Gompel, J.; Arani, A.; Meyer, F.; Lanzino, G.; Link, M.J.; Ehman, R.; Huston, J. Higher-Resolution Magnetic Resonance Elastography in Meningiomas to Determine Intratumoral Consistency. Neurosurgery 2015, 77, 653-659. [CrossRef]

65. Streitberger, K.J.; Reiss-Zimmermann, M.; Freimann, F.B.; Bayerl, S.; Guo, J.; Arlt, F.; Wuerfel, J.; Braun, J.; Hoffmann, K.T.; Sack, I. High-Resolution Mechanical Imaging of Glioblastoma by Multifrequency Magnetic Resonance Elastography. PLoS ONE 2014, 9, e110588. [CrossRef]

66. Fernandez-Fuente, G.; Mollinedo, P.; Grande, L.; Vazquez-Barquero, A.; Fernandez-Luna, J.L. Culture Dimensionality Influences the Resistance of Glioblastoma Stem-like Cells to Multikinase Inhibitors. Mol. Cancer Ther. 2014, 13, 1664-1672. [CrossRef]

67. Lee, J.; Kotliarova, S.; Kotliarov, Y.; Li, A.; Su, Q.; Donin, N.M.; Pastorino, S.; Purow, B.W.; Christopher, N.; Zhang, W.; et al. Tumor Stem Cells Derived from Glioblastomas Cultured in bFGF and EGF More Closely Mirror the Phenotype and Genotype of Primary Tumors than do Serum-Cultured Cell Llines. Cancer Cell 2006, 9, 391-403. [CrossRef] [PubMed]

68. Stringer, B.W.; Day, B.W.; D’Souza, R.C.; Jamieson, P.R.; Ensbey, K.S.; Bruce, Z.C.; Lim, Y.C.; Goasdoué, K.; Offenhäuser, C.; Akgül, S.; et al. A Reference Collection of Patient-derived Cell Line and Xenograft Models of Proneural, Classical and Mesenchymal Glioblastoma. Sci. Rep. 2019, 9, 4902. [CrossRef] [PubMed]

69. Kogiso, M.; Qi, L.; Braun, F.K.; Injac, S.G.; Zhang, L.; Du, Y.; Zhang, H.; Lin, F.Y.; Zhao, S.; Lindsay, H.; et al. Concurrent Inhibition of Neurosphere and Monolayer Cells of Pediatric Glioblastoma by Aurora A Inhibitor MLN8237 Predicted Survival Extension in PDOX Models. Clin. Cancer Res. 2018, 24, 2159-2170. [CrossRef] [PubMed]

70. ngsmore, K.M.; Logsdon, D.K.; Floyd, D.H.; Peirce, S.M.; Purow, B.W.; Munson, J.M. Interstitial Flow Differentially Increases Patient-Derived Glioblastoma Stem Cell Invasion via CXCR4, CXCL12, and CD44-mediated Mechanisms. Integr. Biol. 2016, 8, 1246-1260. [CrossRef]

71. Miroshnikova, Y.A.; Mouw, J.K.; Barnes, J.M.; Pickup, M.W.; Lakins, J.N.; Kim, Y.; Lobo, K.; Persson, A.I.; Reis, G.F.; McKnight, T.R.; et al. Tissue Mechanics Promote IDH1-dependent HIF1 $\alpha$-Tenascin C Feedback to Regulate Glioblastoma Aggression. Nat. Cell Biol. 2016, 18, 1336-1345. [CrossRef]

72. Marumoto, T.; Zhang, D.; Saya, H. Aurora-A-A Guardian of Poles. Nat. Rev. Cancer 2005, 5, 42-50. [CrossRef]

73. Smith, S.J.; Wilson, M.; Ward, J.H.; Rahman, C.V.; Peet, A.C.; Macarthur, D.C.; Rose, F.R.; Grundy, R.G.; Rahman, R. Recapitulation of Tumor Heterogeneity and Molecular Signatures in a 3D Brain Cancer Model with Decreased Sensitivity to Histone Deacetylase Inhibition. PLoS ONE 2012, 7, e52335. [CrossRef]

74. Cockle, J.V.; Brüning-Richardson, A.; Scott, K.J.; Thompson, J.; Kottke, T.; Morrison, E.; Ismail, A.; Carcaboso, A.M.; Rose, A.; Selby, P.; et al. Oncolytic Herpes Simplex Virus Inhibits Pediatric Brain Tumor Migration and Invasion. Mol. Ther. Oncolytics 2017, 5, 75-86. [CrossRef] [PubMed]

75. Ogawa, J.; Pao, G.M.; Shokhirev, M.N.; Verma, I.M. Glioblastoma Model Using Human Cerebral Organoids. Cell Rep. 2018, 23, 1220-1229. [CrossRef] [PubMed]

76. Azzarelli, R. Organoid Models of Glioblastoma to Study Brain Tumor Stem Cells. Front. Cell Dev. Biol. 2020, 8, 220. [CrossRef] [PubMed]

77. Nayernia, Z.; Turchi, L.; Cosset, E.; Peterson, H.; Dutoit, V.; Dietrich, P.Y.; Tirefort, D.; Chneiweiss, H.; Lobrinus, J.A.; Krause, K.H.; et al. The Relationship Between Brain Tumor Cell Invasion of Engineered Neural Tissues and Features of Glioblastoma. Biomaterials 2013, 34, 8279-8290. [CrossRef]

78. Fan, Y.; Nguyen, D.T.; Akay, Y.; Xu, F.; Akay, M. Engineering a Brain Cancer Chip for High-Throughput Drug Screening. Sci. Rep. 2016, 6, 25062. [CrossRef]

79. Souza, G.R.; Molina, J.R.; Raphael, R.M.; Ozawa, M.G.; Stark, D.J.; Levin, C.S.; Bronk, L.F.; Ananta, J.S.; Mandelin, J.; Georgescu, M.M.; et al. Three-Dimensional Tissue Culture Based on Magnetic Cell Levitation. Nat. Nanotechnol. 2010, 5, 291-296. [CrossRef]

80. Weeber, F.; van de Wetering, M.; Hoogstraat, M.; Dijkstra, K.K.; Krijgsman, O.; Kuilman, T.; Gadellaa-van Hooijdonk, C.G.; van der Velden, D.L.; Peeper, D.S.; Cuppen, E.P.; et al. Preserved Genetic Diversity in Organoids Cultured from Biopsies of Human Colorectal Cancer Metastases. Proc. Natl. Acad. Sci. USA 2015, 112, 13308-13311. [CrossRef]

81. Singh, S.K.; Clarke, I.D.; Terasaki, M.; Bonn, V.E.; Hawkins, C.; Squire, J.; Dirks, P.B. Identification of a Cancer Stem Cell in Human Brain Tumors. Cancer Res. 2003, 63, 5821-5828. [PubMed]

82. Wang, Z.; Hu, P.; Tang, F.; Lian, H.; Chen, X.; Zhang, Y.; He, X.; Liu, W.; Xie, C. HDAC6 Promotes Cell Proliferation and Confers Resistance to Temozolomide in Glioblastoma. Cancer Lett. 2016, 379, 134-142. [CrossRef]

83. Bar, E.E.; Chaudhry, A.; Lin, A.; Fan, X.; Schreck, K.; Matsui, W.; Piccirillo, S.; Vescovi, A.L.; DiMeco, F.; Olivi, A.; et al. Cyclopamine-mediated Hedgehog Pathway Inhibition Depletes Stem-like Cancer Cells in Glioblastoma. Stem Cells 2007, 25, 2524-2533. [CrossRef] [PubMed]

84. Yu, K.K.H.; Taylor, J.T.; Pathmanaban, O.N.; Youshani, A.S.; Beyit, D.; Dutko-Gwozdz, J.; Benson, R.; Griffiths, G.; Peers, I.; Cueppens, P.; et al. High Content Screening of Patient-derived Cell Lines Highlights the Potential of Non-standard Chemotherapeutic Agents for the Treatment of Glioblastoma. PLoS ONE 2018, 13, e0193694. [CrossRef] [PubMed]

85. Hemmati, H.D.; Nakano, I.; Lazareff, J.A.; Masterman-Smith, M.; Geschwind, D.H.; Bronner-Fraser, M.; Kornblum, H.I. Cancerous Stem Cells Can Arise from Pediatric Brain Tumors. Proc. Natl. Acad. Sci. USA 2003, 100, 15178-15183. [CrossRef] 
86. Badekila, A.K.; Kini, S.; Jaiswal, A.K. Fabrication Techniques of Biomimetic Scaffolds in Three-dimensional Cell Culture: A Review. J. Cell. Physiol. 2021, 236, 741-762. [CrossRef] [PubMed]

87. Ozturk, M.S.; Lee, V.K.; Dai, G.; Intes, X. Longitudinal Volumetric Assessment of Glioblastoma Brain Tumors in 3D Bio-Printed Environment by Mesoscopic Fluorescence Molecular Tomography. In Proceedings of the Cancer Imaging and Therapy 2016, Fort Lauderdale, FL, USA, 25-28 April 2016; pp. 3-46.

88. Magno, V.; Meinhardt, A.; Werner, C. Polymer Hydrogels to Guide Organotypic and Organoid Cultures. Adv. Funct. Mater. 2020, 30, 2000097. [CrossRef]

89. Xiao, W.; Wang, S.; Zhang, R.; Sohrabi, A.; Yu, Q.; Liu, S.; Ehsanipour, A.; Liang, J.; Bierman, R.D.; Nathanson, D.A.; et al. Bioengineered Scaffolds for 3D Culture Demonstrate Extracellular Matrix-mediated Mechanisms of Chemotherapy Resistance in Glioblastoma. Matrix Biol. 2019, 85-86, 128-146. [CrossRef]

90. Xu, J.; Margol, A.; Asgharzadeh, S.; Erdreich-Epstein, A. Pediatric Brain Tumor Cell Lines. J. Cell. Biochem. 2015, 116, 218-224. [CrossRef]

91. Dutta, D.; Heo, I.; Clevers, H. Disease Modeling in Stem Cell-Derived 3D Organoid Systems. Trends Mol. Med. 2017, 23, 393-410. [CrossRef] [PubMed]

92. Ho, B.X.; Pek, N.M.Q.; Soh, B.S. Disease Modeling Using 3D Organoids Derived From Human Induced Pluripotent Stem Cells. Int. J. Mol. Sci. 2018, 19, 936. [CrossRef] [PubMed]

93. Chhibber, T.; Bagchi, S.; Lahooti, B.; Verma, A.; Al-Ahmad, A.; Paul, M.K.; Pendyala, G.; Jayant, R.D. CNS Organoids: An Innovative Tool for Neurological Disease Modeling and Drug Neurotoxicity Screening. Drug Discov. Today 2020, 25, 456-465. [CrossRef] [PubMed]

94. Papaioannou, M.D.; Sangster, K.; Sajid, R.S.; Djuric, U.; Diamandis, P. Cerebral Organoids: Emerging Humanoid Models of Glioblastoma. Acta Neuropathol. Commun. 2020, 8, 209. [CrossRef]

95. Lancaster, M.A.; Renner, M.; Martin, C.A.; Wenzel, D.; Bicknell, L.S.; Hurles, M.E.; Homfray, T.; Penninger, J.M.; Jackson, A.P.; Knoblich, J.A. Cerebral Organoids Model Human Brain Development and Microcephaly. Nature 2013, 501, 373-379. [CrossRef]

96. Bian, S.; Repic, M.; Guo, Z.; Kavirayani, A.; Burkard, T.; Bagley, J.A.; Krauditsch, C.; Knoblich, J.A. Genetically Engineered Cerebral Organoids Model Brain Tumor Formation. Nat. Methods 2018, 15, 631-639. [CrossRef]

97. Qian, X.; Song, H.; Ming, G.1. Brain Organoids: Advances, Applications and Challenges. Development 2019, 146, dev166074. [CrossRef]

98. Berger, E.; Magliaro, C.; Paczia, N.; Monzel, A.S.; Antony, P.; Linster, C.L.; Bolognin, S.; Ahluwalia, A.; Schwamborn, J.C. Millifluidic Culture Improves Human Midbrain Organoid Vitality and Differentiation. Lab Chip 2018, 18, 3172-3183. [CrossRef] [PubMed]

99. Sarker, F.A.; Prior, V.G.; Bax, S.; O’Neill, G.M. Forcing a Growth Factor Response-Tissue-Stiffness Modulation of Integrin Signaling and Crosstalk with Growth Factor Receptors. J. Cell Sci. 2020, 133, jcs242461. [CrossRef]

100. An, Z.; Aksoy, O.; Zheng, T.; Fan, Q.W.; Weiss, W.A. Epidermal Growth Factor Receptor and EGFRvIII in Glioblastoma: Signaling Pathways and Targeted Therapies. Oncogene 2018, 37, 1561-1575. [CrossRef] [PubMed]

101. Dababneh, A.B.; Ozbolat, I.T. Bioprinting Technology: A Current State-of-the-art Review. J. Manuf. Sci. Eng. 2014, 136, 061016. [CrossRef]

102. Cui, X.; Gao, G.; Yonezawa, T.; Dai, G. Human cartilage tissue fabrication using three-dimensional inkjet printing technology. J. Vis. Exp. JoVE 2014, 88, 51294. [CrossRef]

103. Wang, W.; Li, G.; Huang, Y. Modeling of bubble expansion-induced cell mechanical profile in laser-assisted cell direct writing. J. Manuf. Sci. Eng. 2009, 131, 051013. [CrossRef]

104. Sun, H.; Jia, Y.; Dong, H.; Dong, D.; Zheng, J. Combining Additive Manufacturing with Microfluidics: An Emerging Method for Developing Novel Organs-on-Chips. Curr. Opin. Chem. Eng. 2020, 28, 1-9. [CrossRef]

105. Gungor-Ozkerim, P.S.; Inci, I.; Zhang, Y.S.; Khademhosseini, A.; Dokmeci, M.R. Bioinks for 3D Bioprinting: An Overview. Biomater. Sci. 2018, 6, 915-946. [CrossRef] [PubMed]

106. Zhao, Y.; Yao, R.; Ouyang, L.; Ding, H.; Zhang, T.; Zhang, K.; Cheng, S.; Sun, W. Three-dimensional Printing of Hela Cells for Cervical Tumor Model. Biofabrication 2014, 6, 035001. [CrossRef] [PubMed]

107. Lee, V.K.; Dai, G.; Zou, H.; Yoo, S.S. Generation of 3-D glioblastoma-Vascular Niche using 3-D Bioprinting. In Proceedings of the IEEE 2015 41st Annual Northeast Biomedical Engineering Conference (Nebec), Troy, NY, USA, 17-19 April 2015; pp. 1-2.

108. Mirani, B.; Pagan, E.; Shojaei, S.; Duchscherer, J.; Toyota, B.D.; Ghavami, S.; Akbari, M. A 3D Bioprinted Hydrogel Mesh Loaded with All-Trans Retinoic Acid for Treatment of Glioblastoma. Eur. J. Pharmacol. 2019, 854, 201-212. [CrossRef]

109. Ouyang, L.; Highley, C.B.; Rodell, C.B.; Sun, W.; Burdick, J.A. 3D Printing of Shear-Thinning Hyaluronic Acid Hydrogels with Secondary Cross-Linking. ACS Biomater. Sci. Eng. 2016, 2, 1743-1751. [CrossRef] [PubMed]

110. Suri, S.; Schmidt, C.E. Cell-Laden Hydrogel Constructs of Hyaluronic Acid, Collagen, and Laminin for Neural Tissue Engineering. Tissue Eng. Part A 2010, 16, 1703-1716. [CrossRef]

111. Yi, H.G.; Jeong, Y.H.; Kim, Y.; Choi, Y.J.; Moon, H.E.; Park, S.H.; Kang, K.S.; Bae, M.; Jang, J.; Youn, H.; et al. A Bioprinted Human-Glioblastoma-on-a-Chip for the Identification of Patient-Specific Responses to Chemoradiotherapy. Nat. Biomed. Eng. 2019, 3, 509-519. [CrossRef]

112. Datta, P.; Dey, M.; Ataie, Z.; Unutmaz, D.; Ozbolat, I.T. 3D Bioprinting for Reconstituting the Cancer Microenvironment. NPJ Precis. Oncol. 2020, 4, 1-13. [CrossRef] 
113. Pham, M.T.; Pollock, K.M.; Rose, M.D.; Cary, W.A.; Stewart, H.R.; Zhou, P.; Nolta, J.A.; Waldau, B. Generation of Human Vascularized Brain Organoids. Neuroreport 2018, 29, 588. [CrossRef]

114. Mansour, A.; Gage, F.H.; Ozkan, A.; Kumar, W.; Basak, A.N.; Macklis, J.D.; Pappalardo, Z.; Ohlemscher, S.; Chien, C.C. In Vivo Brain Organoid Model for Generation of Vascularized and Functional PSC-Derived Human Brain Organoids. Neuroscience 2000, $6,163$.

115. Tomasina, C.; Bodet, T.; Mota, C.; Moroni, L.; Camarero-Espinosa, S. Bioprinting Vasculature: Materials, Cells and Emergent Techniques. Materials 2019, 12, 2701. [CrossRef]

116. Lee, C.S.; Leong, K.W. Advances in Microphysiological Blood-brain Barrier (BBB) Models Towards Drug Delivery. Curr. Opin. Biotechnol. 2020, 66, 78-87. [CrossRef] [PubMed]

117. Lim, K.S.; Schon, B.S.; Mekhileri, N.V.; Brown, G.C.; Chia, C.M.; Prabakar, S.; Hooper, G.J.; Woodfield, T.B. New Visible-Light Photoinitiating System for Improved Print Fidelity in Gelatin-Based Bioinks. ACS Biomater. Sci. Eng. 2016, 2, 1752-1762. [CrossRef]

118. Lee, C.; Abelseth, E.; de la Vega, L.; Willerth, S.M. Bioprinting a Novel Glioblastoma Tumor Model Using a Fibrin-Based Bioink for Drug Screening. Mater. Today Chem. 2019, 12, 78-84. [CrossRef]

119. Jahromi, M.A.M.; Abdoli, A.; Rahmanian, M.; Bardania, H.; Bayandori, M.; Basri, S.M.M.; Kalbasi, A.; Aref, A.R.; Karimi, M.; Hamblin, M.R. Microfluidic Brain-on-a-chip: Perspectives for mimicking neural system disorders. Mol. Neurobiol. 2019, 56, 8489-8512. [CrossRef] [PubMed]

120. Murphy, S.V.; De Coppi, P.; Atala, A. Opportunities and Challenges of Translational 3D Bioprinting. Nat. Biomed. Eng. 2020, 4, 370-380. [CrossRef] [PubMed]

121. Mao, H.; Yang, L.; Zhu, H.; Wu, L.; Ji, P.; Yang, J.; Gu, Z. Recent Advances and Challenges in Materials for 3D Bioprinting. Prog. Nat. Sci. Mater. Int. 2020, 30, 618-634. [CrossRef]

122. Brown, T.E.; Marozas, I.A.; Anseth, K.S. Amplified Photodegradation of Cell-Laden Hydrogels via an Addition-Fragmentation Chain Transfer Reaction. Adv. Mater. 2017, 29, 1605001. [CrossRef]

123. Bakarich, S.E.; Gorkin III, R.; Panhuis, M.I.H.; Spinks, G.M. 4D Printing with Mechanically Robust, Thermally Actuating Hhydrogels. Macromol. Rapid Commun. 2015, 36, 1211-1217. [CrossRef]

124. Tomaskovic-Crook, E.; Crook, J.M. 3D Bioprinting Electrically Conductive Bioink with Human Neural Stem Cells for Human Neural Tissues. In 3D Bioprinting; Springer: New York, NY, USA, 2020; pp. 159-170.

125. Zhang, Y.S.; Zhang, Y.N.; Zhang, W. Cancer-on-a-Chip Systems at the Frontier of Nanomedicine. Drug Discov. Today 2017, 22, 1392-1399. [CrossRef] [PubMed]

126. Ma, L.; Barker, J.; Zhou, C.; Li, W.; Zhang, J.; Lin, B.; Foltz, G.; Küblbeck, J.; Honkakoski, P. Towards Personalized Medicine with a Three-dimensional Micro-scale Perfusion-based Two-chamber Tissue Model System. Biomaterials 2012, 33, $4353-4361$. [CrossRef] [PubMed]

127. Han, J.; Oh, S.; Hoang, H.H.; Nguyen, D.T.T.; Lim, W.; Shin, T.H.; Lee, G.; Park, S. Recapitulation of Cancer Stem Cell Niches in Glioblastoma on 3D Microfluidic Cell Culture Devices Under Gravity-driven Perfusion. J. Ind. Eng. Chem. 2018, 62, 352-361. [CrossRef] 